UDC: 581.524

\title{
IMPACT OF NATURAL FACTORS ON POPULATIONS CHANGES \\ OF HERBACEOUS PLANTS SPECIES AND ASSESSMENT OF THEIR STATE IN PRESENT HIGH-MOUNTAIN CONDITIONS OF THE UKRAINIAN CARPATHIANS
}

\author{
R. Dmytrakh \\ Institute of Ecology of the Carpathians, NAS of Ukraine, 4 Kozelnytska St., Lviv 79026, Ukraine \\ Corresponding author e-mail: ecoinst@mail.Iviv.ua
}

Dmytrakh R. Impact of natural factors on population changes of herbaceous plants species and assessment of their state in present high-mountain conditions of the Ukrainian Carpathians. Studia Biologica, 2021: 15(1); 67-78 • DOI: https://doi.org/10.30970/sbi.1501.646

Background. Natural ecosystems of the Ukrainian Carpathians have been significantly transformed during the last few years due to the impact of climate factors and an increased activity of nature restoration processes. The study of the influence of the external environmental factors on populations of the herbaceous plant species is particularly topical for the high-mountain ecosystems. As a result of gradual restoration of native plants, specific changes occur in the structural and spatial organization of populations of many herbaceous plant species. Thus, considering the increased climate changes and regenerative activity, the assessment of the present condition of the populations of herbaceous plant species, their regenerative ability, response to changing environmental conditions and individual peculiarities of performance in the altered environmental conditions are important.

Methods. The conventional stationary and route-field methods were applied in order to determine changes in the structural organization of high-mountain plant populations and their regenerative ability. The initial diagnostic parameters of the populations' condition include the individual growth peculiarities and the nature of dynamic trends under the changed environmental conditions. During the ontogenetic development of plants, the most important changes occur within the generative phase that ensures the regeneration and self-maintenance of populations by means of seeds; those changes are a significant indicative feature. The long-term observations of different types of plant communities were applied; these included the records of the main parameters and characteristic features at permanent test sites. The transects are located in the alpine, subalpine and upper forest belts of the Ukrainian Carpathians within 1000-2000 m a.s.l. altitudinal range. The study comprises such behavioral features of the species populations

() 2021 R. Dmytrakh. Published by the Ivan Franko National University of Lviv on behalf of Біологічні Студії / Studia Biologica. This is an Open Access article distributed under the terms of the Creative Commons Attribution License (http://www.budapestopenaccessinitiative.org and Creative Commons Attribution 4.0 License), which permits unrestricted reuse, distribution, and reproduction in any medium, provided the original work is properly cited.

ISSN 1996-4536 (print) • ISSN 2311-0783 (on-line) • Біологічні Студії / Studia Biologica • 2021 • Том 15 / № 1 • С. $67-78$ 
as phenological (intensity phenophase, flowering rhythmics), demographic (number of individuals, spatial differentiation), reproductive (generative reproduction, seed productivity), etc., which enable the determination of their adaptation and ability to exist under the changed environmental conditions.

Results. The continuous monitoring of different high-mountain plant aggregations showed that in some cases the number of species which are distinguished by active regenerative strategy aimed at further extension of the habitat is growing, while in other cases the species demonstrated the opposite trend resulting from their inability to adapt to changing habitat conditions. It has been determined that the vegetative development of the populations of high-mountain plant species is closely related to temperature conditions which influence phenology, dynamics of the numbers of individuals and the nature of their reproduction. A significant influence of warming on the processes of seasonal development of populations and flowering abundance is evidenced by their increased number and migration to much higher hypsometric levels of the high-mountain zone. The increased ability to generative reproduction contributes to the dissemination of seeds and formation of new population loci Valeriana simplicifolia, V. transsilvanica, Silene dioica, Astrantia major, Doronicum carpaticum, Euphorbia carniolica, etc. in favourable micro-habitats at significantly higher hypsometric levels of the high-mountain zone (1600-2000 m a.s.I.). Another natural factor of changes in populations of herbaceous plant species is the impact of restoration succesions in different types of plant communities. These changes are usually accompanied by increased shading and crowding of vegetation due to the spread of more competitive tree and shrub species as well as adventive species of tall herbaceous plants. It refers mostly to grassland species that need open sites for the effective population recruitment. Radical changes can be observed in the structural organization of the populations of herbaceous plants species due to an increased cenotic activity of more competitive species. Such changes reduce the regenerative ability of the populations of herbaceous plants species and trigger their fragmentation. Thus, the change of ecological and cenotic conditions of various plant communities along the elevation gradient of the highlands predetermines different characteristic features of the populations of herbaceous plant species and their unequal spatial differentiation.

Conclusions. It has been determined that present natural processes occurring in the populations of herbaceous plant species of the high-mountain zone controversially influence their regenerative ability and the nature of changes in their structural organization. The dynamics of populations in each separate case is defined by the influence of natural and climate changes and their association with particular plant communities along the elevation gradient of the high-mountain zone. The multi-year dynamics of the numbers of generative individuals represents their regenerative ability in populations and dependence on weather conditions. The important feature of active regeneration of the populations is the development of their local foci in favorable microhabitats at significantly higher hypsometric levels of the high-mountain zone, in particular, the alpine and the upper margin of the alpine. Occurrence of new populations loci is indicative of their ability to reproduce and survive. In some cases, the dynamic trends in populations are accompanied by an increased number of individuals and extension of their habitats, while in other cases, trends are the opposite, which is caused by a decreased number of individuals and their degradation. The processes which are observed during the regeneration of species populations are related to their ascending extension to various hypsometric

ISSN 1996-4536 (print) • ISSN 2311-0783 (on-line) • Біологічні Студії / Studia Biologica • 2021 • Том 15 / № 1 • C. 67-78 
levels, as well as the strengthening of the positions of the populations of tree and shrub layer species and adventive representatives of tall herbaceous plants which are peculiar to lower layers. Significant overgrowth processes, which result in gradual exclusion of herbaceous plant species typical of meadow communities aggregations, are observed in the habitats of the populations of many types of herbaceous plants and at the upper margin of the forest and subalpine layers. Thus, the changes in ecological and cenotic conditions of various plant communities along the elevation gradient of the highlands predetermines different characteristic features of the populations of herbaceous plant species and their unequal spatial differentiation.

Keywords: climate changes, generative reproduction, restore in population, highmountain zone

\section{INTRODUCTION}

The high-mountain zone of the Ukrainian Carpathians has demonstrated an active regeneration of the herbaceous cover, particularly that of the protected areas, which have been significantly transformed due to present climate changes for the last decade. The study of the influence of the external environmental factors on populations of herbaceous plant species is particularly topical for the high-mountain ecosystems $[9,12$, $14,16]$. These factors predetermine the various abilities of the populations of the highmountain species for reproduction and functioning [7, 10, 13, 15].

The most significant natural factor that causes transformations of biota is the climate change and restoration succession. The highland plant species quite actively respond to the change of climate factors $[3,4,8,18,21]$. The relevant outcomes are primarily caused by the influence of air temperature. According to the results of recent climate studies, the mean air temperature has increased by $0.4-1.5^{\circ} \mathrm{C}$ for the last 100 years. The prolongation of vegetative period, raise of the effective temperatures, quicker snow melting, and a decrease in winter precipitation cause transformations of habitats and biotopes. Following the climate changes, the specific alterations in the structure of populations of many high-mountain species, dislocation of their altitudinal zonation, cenotic transformations and an increased participation of shrubs, adventive representatives of tall herbaceous plants and sod grasses in the succession can be observed.

Considering the increased climate changes and regenerative activity in the highlands, the assessment of the present condition of the populations of herbaceous plant species and peculiarities of their performance in the altered environmental conditions is important. Previous studies proved that the populations of high-mountain species possess different ability for self-regeneration and preservation of their structural and functional organization under the influence of external environmental factors and display individual behavioral, adaptation and survival patterns [2, 6, 14, 19].

The aim of the study is to determine the specific changes in the populations of herbaceous plant species of the high-mountain zone, in particular, their response to changing environmental conditions, peculiarities of dynamic trends and regenerative ability due to an increased influence of climate factors and activation of regenerative processes. The study comprises such behavioral features of the species populations as phenological (phenophase duration and development rate, flowering rhythmics), demographic (number, density, spatial differentiation), reproductive (generative reproduction, seed productivity, viability of seedlings), etc., which enable the determination of their adaptation and

$\overline{\text { ISSN 1996-4536 (print) • ISSN 2311-0783 (on-line) • Біологічні Студії / Studia Biologica • } 2021 \text { • Том 15 / № 1 • C. } 67-78}$ 
ability to exist under the changed environmental conditions. The obtained results are important for settling the issues related to preservation and protection of the populations of high-mountain species and the forecast of their behavior under ecologically changed conditions of the high-mountain zone.

\section{MATERIALS AND METHODS}

The conventional stationary and route-field methods were applied in order to determine changes in the structural organization of high-mountain plant populations and their regenerative ability $[17,22,23]$. The initial diagnostic parameters of the populations' condition include the individual growth peculiarities and the nature of dynamic trends under the changed environmental conditions. The long-term observations of different types of plant aggregations were applied for this purpose; these included the records of the main parameters and characteristic features at permanent test sites. Stationary research on changes in the population structure was carried out both on the previously established long-term monitoring transects and on the new sites. The transects are located in the alpine, subalpine and upper forest belts of the Ukrainian Carpathians within 1000-2000 $\mathrm{m}$ a.s.l. altitudinal range. The research covered mountain massif of the Chornohora, Svydovets and Beskydy ranges within different habitat types that differ in their eco-coenotic characteristics. Most of the transects are located in the central part of the Chornohora range in the vicinity of the High-mountain Biological Station of the Institute of Ecology of the Carpathians, NAS of Ukraine.

During the ontogenetic development of plants, the most important changes occur within the generative phase that ensures the regeneration and self-maintenance of populations by means of seeds; those changes are a significant indicative feature [2, 5, 20]. The nature of phenophases advancement in the course of the seasonal population development was assessed, and, in particular, the flowering rhythms, changes in the number of individuals and the dependence of this parameter on weather conditions $[1,11]$. The climate indices of Pozhyzhevska snow-avalanche weather station (1450 m a.s.l.) of Ivano-Frankivsk Hydrometeorological Center of the State Emergency Service of the Chornohora Mountain massif of the Ukrainian Carpathians were used for this purpose. The air temperature values, the total amount of atmospheric precipitation, the duration of solar insolation and other parameters were considered and analyzed in different vegetation periods (1981-2020).

The research objects were the populations of high-mountain plant species that occur in different plant aggregations and are located at different high-mountain hypsometric levels (Achillea carpatica Bloki ex Dubovik, Antennaria dioica (L.) Gaertn., Astrantia major L., Cardamine amara L., Dianthus carpaticus Wołoszcz., D. compactus Kit., Doronicum carpaticum (Griseb. et Schenk) Nym., Epilobium hirsutum L., Euphorbia carniolica Jacg., Laserpitium krapfii Crantz, Rumex carpaticus Zapał., Senecio subalpinus Koch, Silene dioica (L.) Clairv, Solidago alpestris Waldst. et Kit, Thymus alpestris Tausch, Th. pulcherrimus Schur, Valeriana transsilvanica Schur, V. tripteris L., V. simplicifolia (Reichenb.) Kabath et al.). The great majority of them are local populations of the upper forest, subalpine and alpine zones of the Ukrainian Carpathians according to the peculiarities of the spatial migration. The selected research objects represent various bio-morphological types and differ in their ecological needs (swamp, meadow, petrophytous species etc.), coenotic role (dominants, subdominants, companions) and are representative for the high-mountain communities of the Ukrainian Carpathians.

ISSN 1996-4536 (print) • ISSN 2311-0783 (on-line) • Біологічні Студії / Studia Biologica • 2021 • Том 15 / № 1 • C. 67-78 


\section{RESULTS AND DISCUSSION}

The multi-year observations of the herbaceous plant populations in the Ukrainian Carpathians showed that the changes occurring in seasonal dynamics of their development are closely related to the temperature values during different vegetation periods. The increase in air temperature, intensity of atmospheric precipitation and changes of insolation values determine different possibilities of adaptation and survival for populations of species under present high-mountain conditions. Based on the analysis of meteorological data for the recent decades, we observed a tendency towards an increase in air temperature values, particularly, the maximum values reaching $25^{\circ} \mathrm{C}$ in July-August, in the yearly cycles of vegetation growth. The comparison of meteorological data for the previous period (1985-1999) and that for the present period (2000-2019) showed that the average monthly air temperature during vegetation seasons (MaySeptember) increased by $1.2^{\circ} \mathrm{C}$; the temperature maximum of July increased by $3.8^{\circ} \mathrm{C}$.

A significant influence of warming on the processes of seasonal development of the populations and flowering abundance is evidenced by the increased number of generative individuals, the share of which increased twofold or threefold. It made a positive impact on dissemination and extension of the population habitats of a range of highmountain forb and meadow species. The rapid response of the generative individuals to the changes in the temperature values is particularly evident in open high-mountain areas with sufficient insolation. The dynamics of the numbers of generative individuals is illustrated by populations of Valeriana simplicifolia, V. tripteris, Thymus alpestris, Antennaria dioica (Fig. 1).

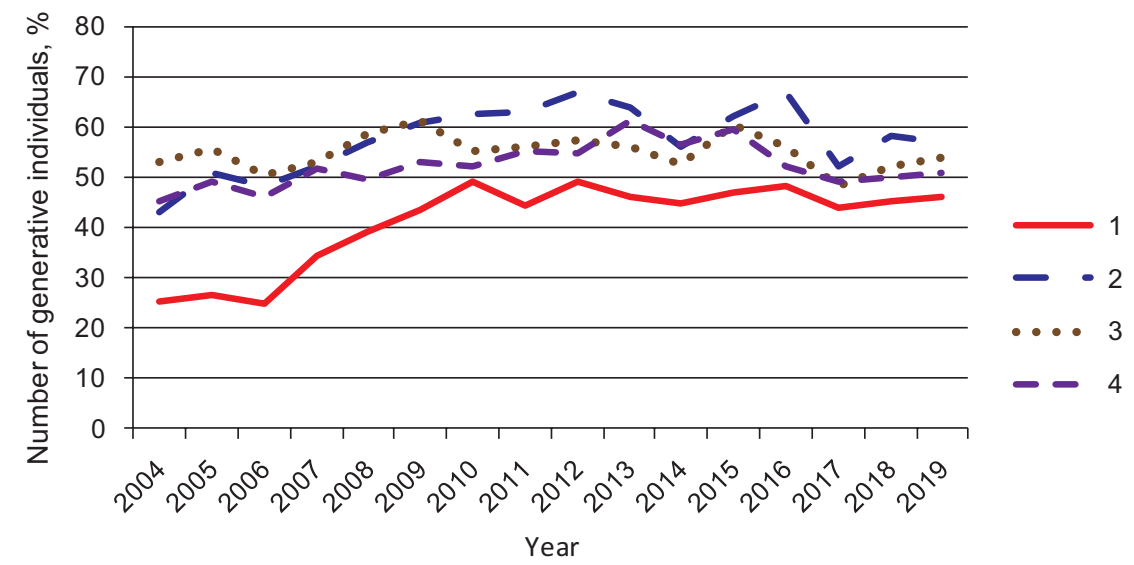

Fig. 1. Dynamics of the numbers of generative individuals in populations of the herbaceous plant species: 1 - Valeriana simplicifolia; 2 - V. tripteris; 3 - Thymus alpestris; 4 - Antennaria dioica

Рис. 1. Динаміка чисельності генеративних особин у популяціях видів трав'яних рослин: 1 - Valeriana simplicifolia; 2 - V. tripteris; 3 - Thymus alpestris; 4 - Antennaria dioica

Thus, the vegetation development of the populations of herbaceous plant species is closely related to temperature conditions of the high-mountain zone and shows the populations' response to the changes of the conditions. The influence of warm weather and, in particular, an increased air temperature, triggers significant time variations of the phenological cycles of the plants. The studies performed on populations of the herbaceous plant species showed that the changes in phenological development are observed 
following the warming initiated by the increased air temperature. Such changes result in the increased flowering rhythm and dislocation of flowering stages to earlier vegetation periods. Flowering becomes more abundant and the intensity of phenophases development increases. The course of seasonal development of populations represents the adaptation and the nature of cycle changes in the numbers of individuals in the populations under present conditions. The greatest changes in the numbers of individuals and dislocation of their flowering rhythms were observed when the average monthly air temperature increased from $9.3^{\circ} \mathrm{C}$ to $12.0^{\circ} \mathrm{C}$ as compared with $1990-1999$.

The increased ability for generative reproduction contributes to dissemination of seeds and formation of new population loci in favorable microhabitats at significantly higher hypsometric levels of the high-mountain zone (1600-2000 m a.s.I.). The studies performed at monitoring sites showed a significantly increased activity of the seedlings viability. In particular, their number in populations of Valeriana simplicifolia, V. tripteris, V. transsilvanica, Rumex carpaticus, Thymus alpestris, Euphorbia carniolica, Laserpitium krapfii, Silene dioica has increased from $10(15) \mathrm{pc} . / \mathrm{m}^{2}$ to $35(40) \mathrm{pc} . / \mathrm{m}^{2}$ for the last period of studies.

An important feature of the active regeneration of the populations is the development of their local foci at different herbaceous layers of the high-mountain zone. For instance, the newly formed habitats of Valeriana simplicifolia populations, which are usually located in the lower mountain basins (1200-1340 m a.s.l.) are found at much higher hypsometric levels of the highlands (1400-1600 m a.s.l.). The developmental dynamics of one of such loci in the Breskul-Pozhyzhevska mountain area of the Chornohora Mountain massif is presented in Fig. 2. The multi-year observations of the newly formed (in 2010) locus showed positive dynamics of the numbers of generative individuals and gradual extension of its boundaries. The flowering abundance of the generative individuals reaches its peak in 2013 and 2019. Thus, the numbers of

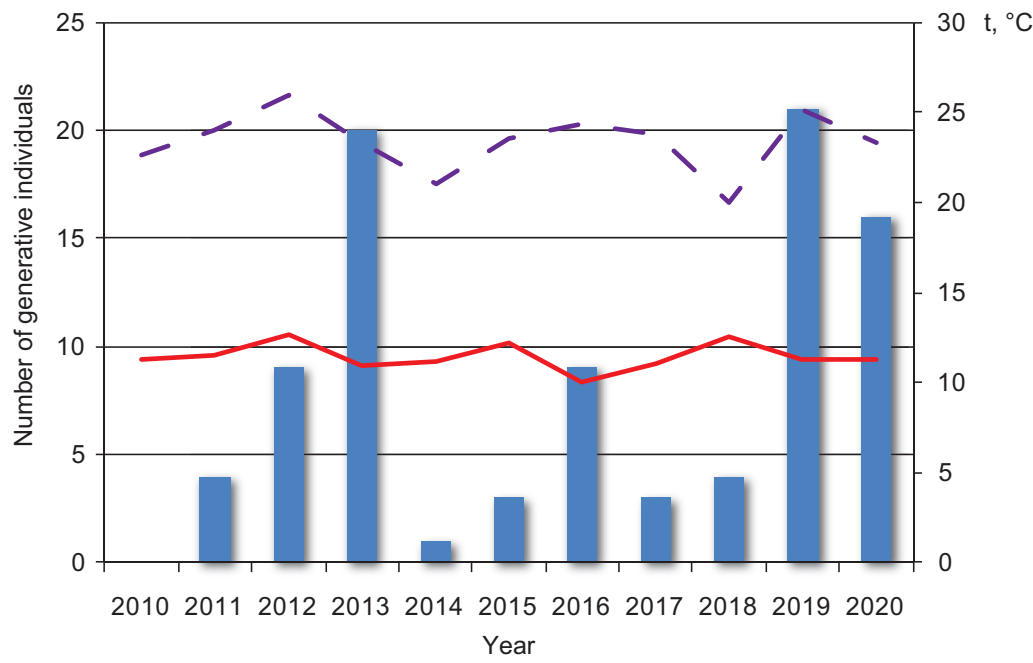

Fig. 2. Dynamics of the numbers of generative individuals in the newly formed locus of Valeriana simplicifolia (Reichenb.) Kabath.; - - average monthly air temperature, ${ }^{\circ} \mathrm{C}$; - - - maximum air temperature (July), ${ }^{\circ} \mathrm{C}$

Рис. 2. Динаміка чисельності генеративних особин в новоутвореному локусі Valeriana simplicifolia (Reichenb.) Kabath.; - - середньомісячна температура повітря, ${ }^{\circ} \mathrm{C} ;$ - - - - максимальна температура повітря (липень), ${ }^{\circ} \mathrm{C}$

ISSN 1996-4536 (print) • ISSN 2311-0783 (on-line) • Біологічні Студії / Studia Biologica • 2021 • Том 15 / № 1 • C. 67-78 
generative individuals are clearly correlated with the temperature values during different vegetation seasons. The greatest activity of their development and, in particular, prefoliation, which occurs in the autumn of the previous season, was recorded within the period when the average monthly air temperature increased to $12.7^{\circ} \mathrm{C}$ in 2012 and 2018 , and the maximum temperature value in July reached $26.0^{\circ} \mathrm{C}$.

Another natural factor of changes in the populations of herbaceous plant species is the impact of restoration succesions in their habitats. These changes are usually accompanied by increased shading and crowding of vegetation due to the of spread of highly competitive species. Consequently, low-statured species disappear from the communities. In the high-mountain zone of the Ukrainian Carpathians, it refers mostly to grassland species that need open sites for the effective population recruitment. The overgrowth with the forest and shrubby vegetation leads to simplification of the spatial structure, fragmentation and decrease in density of populations, their elimination from the community structure and, consequently, general depletion of the floristic composition of phytocoenoses. Following the acceleration of the regenerative processes enhanced by the climate changes in the high-mountain zone, the dissemination activity of trees and shrubs (Alnus viridis (Chaix) Opiz, Pinus mugo Turra, Salix silesiaca Willd., Juniperus sibirica Bungsd., Picea abies (L.) Karst. et al.), dwarf shrubs (Vaccinium myrtillus L., Vaccinium vitis-idaea L., Rubus idaeus L.) and adventive species of tall herbaceous plants also increased. Thus, the significant overgrowth processes, which result in a gradual exclusion of herbaceous plant species typical of meadow communities aggregations, are observed in the habitats of the populations of many types of herbaceous plants and, in particular, at the upper margin of the forest and subalpine layers.

Similar tendencies towards occurrence of new population loci and their migration to different highland zones are typical of many other highland populations. In particular, separate loci of Silene dioica and Astrantia major populations were found in previously uninvaded regions of meadow aggregations of the upper subalpine zone (1500$16000 \mathrm{~m}$ a.s.l.), and the loci of the species aggregations of Valeriana transsilvanica, Doronicum carpaticum, Cardamine amara, Epilobium hirsutum, etc. located near springs were found at the upper margin of the alpine zone (1800-1900 m a.s.l.).

The change in ecological and cenotic conditions of various plant communities along the elevation gradient of the highlands predetermines different characteristic features of existence of the populations of herbaceous plant species and their unequal spatial differentiation. For example, the populations of Valeriana transsilvanica, V. tripteris, V. simplicifolia, Doronicum carpaticum, Euphorbia carniolica, Rumex carpaticus etc. characterized by high density of individuals under favorable ecological and cenotic conditions suffered great changes due to active overgrowth by Alnus viridis. At present stage of the study, the number and density of the individuals decreased twofold compared with the previous period (1990-2000). The differentiation of population loci and number of generative individuals under various ecological and cenotic conditions and at different hypsometric levels of the high-mountain zone are illustrated by Valeriana transsilvanica and Thymus alpinus (Table).

The values of the reproductive ability of populations significantly decreased and the tendency towards their spatial fragmentation increased due to the enhancement of fitocenotic role of the competitive species and deterioration of the living conditions of herbaceous plant species. The biggest changes occur during the reproductive phase due to dense overgrowth of the habitats by tree and shrub species and a decreased insolation. For example, the lowest values in populations of Valeriana transsilvanica are observed

ISSN 1996-4536 (print) • ISSN 2311-0783 (on-line) • Біологічні Студії / Studia Biologica • 2021 • Том 15 / № 1 • С. $67-78$ 
in the case of overgrowth by Alnus viridis (1300-1500 m a.s.I.) and under canopy of a spruce-fir forest (1000-1200 m a.s.I.). In particular, Alnus viridis actively protrudes into the populations of meadow species from the forest and lower subalpine layers and exhibits the tendency towards the extension of its boundaries.

\section{Change of reproductive ability values in the populations of Valeriana transsilvanica Schur and Thymus alpestris Tausch}

Зміни показників репродуктивної здатності в популяціях Valeriana transsilvanica Schur and Thymus alpestris Tausch

\begin{tabular}{|c|c|c|c|c|}
\hline \multirow[b]{2}{*}{ Conditions } & \multicolumn{2}{|c|}{ Valeriana transsilvanica } & \multicolumn{2}{|c|}{ Thymus alpestris } \\
\hline & $\begin{array}{c}\text { Number of } \\
\text { generative } \\
\text { individuals } / \mathrm{m}^{2}\end{array}$ & $\begin{array}{l}\text { Number of } \\
\text { flowers of one } \\
\text { individual }\end{array}$ & $\begin{array}{c}\text { Number of } \\
\text { generative } \\
\text { individuals } / \mathrm{m}^{2}\end{array}$ & $\begin{array}{l}\text { Number of } \\
\text { flowers of one } \\
\text { individual }\end{array}$ \\
\hline $\begin{array}{l}\text { Under canopy of a spruce-fir } \\
\text { forest (1000-1200 m a.s.l.) }\end{array}$ & $0.6 \pm 0.2$ & $125 \pm 0.3$ & $0.5 \pm 0.1$ & $26.4 \pm 0.3$ \\
\hline $\begin{array}{l}\text { Complete shrubbing by Alnus } \\
\text { viridis ( } 1300-1500 \mathrm{~m} \text { a.s.I.) }\end{array}$ & $1.3 \pm 0.2$ & $176 \pm 0.3$ & $1.6 \pm 0.2$ & $33.3 \pm 0.2$ \\
\hline $\begin{array}{l}\text { Subalpine zone, openmeadow } \\
\text { areas (1600-1800 m a.s.I.) }\end{array}$ & $2.0 \pm 0.3$ & $198 \pm 0.4$ & $1.9 \pm 0.3$ & $35.2 \pm 0.3$ \\
\hline
\end{tabular}

The characteristic feature is an active overgrowth of highland meadow aggregations by representatives of more competitive tall herbaceous plant species (Chamanerion angustifolium (L.) Holub, Senecio nemorensis Moench, Filipendula denudate (L. et C. Presl) Fritsch, Cirsium waldsteinii Rony, Rumex alpinus L., Urtica dioica L. et al.). In general, the situation is particularly negative for populations of meadow heliophilic species in virtually all high-mountain regions; it results in their spatial differentiation and fragmentation. The populations of species lose the reproductive and regenerative abilities under conditions of complete invasion of shrubs. The overgrowth caused by the unfinished reproductive succession is peculiar to protected areas after the grazing season. It is mostly related to the populations of meadow fitocenotic species that are located in the lower plant layers of the highlands and suffer significant changes due to the overgrowth and an increased density of tall herbaceous plant and shrub cenoses. It has a direct impact on the demographic and spatial structures of the populations and, first and foremost, on their ability to disseminate and regenerate.

\section{CONCLUSIONS}

It has been determined that present natural transformation processes occurring in the populations of herbaceous plant species of the high-mountain zone controversially influence their regenerative ability and the nature of changes in their structural organization. The dynamics of populations in each separate case is defined by the influence of natural and climate changes and their association with particular plant communities along the elevation gradient of the high-mountain zone. In some cases, the dynamic trends in populations are accompanied by an increased number of individuals and extension of their habitats, while in other cases, the changes are the opposite, which is caused by a decrease in the numbers of individuals and their fragmentation. The processes observed during the regeneration of species populations are related to their

ISSN 1996-4536 (print) • ISSN 2311-0783 (on-line) • Біологічні Студії / Studia Biologica • 2021 • Том 15 / № 1 • C. 67-78 
ascending extension to various hypsometric levels, as well as the strengthening of the positions of the populations of tree and shrub layer species and adventive representatives of tall herbaceous plants which are typical of lower layers. The regenerative ability of populations, initiated by warming, is only possible if they are located in habitats with favorable ecological and cenotic conditions. The positive dynamics in populations is observed under such conditions; it is caused by an increased number of generative individuals, their flowering intensity and reproductive ability. The multi-year dynamics of the numbers of generative individuals represents their regenerative ability in populations and dependence on weather conditions. Population loci are important for the conservation of herbaceous species populations and the prospects for their further existence. They are the population nuclei of plant communities. Accordingly, they are the centers of conservation and restoration of species populations.

Thus, the protection measures should be differentiated depending on the relation of population localities to different habitat conditions. In order to contribute to natural regeneration of populations it is necessary to ensure the preservation of the population loci located in risk zones and are distinguished by signs of degradation. It is necessary to initiate a program for comprehensive research of the populations of herbaceous plant species in order to facilitate conservation and avoid biodiversity loss in the high-mountain zone of the Ukrainian Carpathians.

\section{COMPLIANCE WITH ETHICAL STANDARDS}

Conflict of Interest: The authors declare that the research was conducted in the absence of any commercial or financial relationships that could be construed as a potential conflict of interest.

Animal Rights: This article does not contain any studies with animal subjects performed by the any of the authors.

1. Baeten L., De Frenne P., Verheyen K., Graae B.J., Hermy M. Forest herbs in the face of global change: a single-species-threats approach for Anemone nemorosa. Plant Ecology and Evolution, 2010; 143(1): 19-30.

Crossref $\bullet$ Google Scholar

2. Bilonoga V., Gynda L., Danylyk I., Dmytrakh R., Zhilyaev G., Kyyak V., Kobiv V., Kodiv Y., Mykitchak T., Nesteruk Y., Reshetylo O., Serednytska S., Sytschak N., Sosnovska S., Tsaryk Y., Shtupun V. The mechanism of self-renewel of populations. (Ed. Y. Tsaryk). Lviv: Spolom, 2014. 216 p. (In Ukrainian)

3. Didukh Y. Ecological aspects of the global climate changes: reasons, consequences and actions. Bulletin National Academy of Science of Ukraine, 2009; 2: 34-44. (In Ukrainian) Google Scholar

4. DidukhY.P., Chorney I.I. Climatogenic changes of plant life of the Ukrainian Carpathians. Chernivtsi: Druk Art, 2016. 280 p. (In Ukrainian)

Google Scholar

5. Dmytrakh R. Seed reproduction of the high-mountain plant species and characteristics of seed restoration of populations in the Ukrainian Carpathians. Scientific Bulletin of UNFU, 2010; 20(9): 45-51. (In Ukrainian)

Google Scholar

6. Dmytrakh R. Recruitment of populations of the heterosexual plant species in different natural and anthropogenic conditions. Scientific Bulletin of UNFU, 2012; 22(13): 76-81. (In Ukrainian) Google Scholar 
7. Gynda L., Bilonoga V., Dmytrakh R., Kyyak V., Shtupun V. Impact of climate change on the biodiversity of rare and protected vascular plant occurring in high mountain areas of the Ukrainian Carpathians. Biogeography of the Carpathians: Ecological and evolutionary facets of biodiversity. Studia Universitatis Babeş-Bolyai. Biologia, 2017; 62(1): 117-118.

Google Scholar

8. Kobiv Y. Global climate change as a threat to the species biodiversity in the high-mountain zone of the Ukrainian Carpathians. Ukrainian Botanical Journal, 2009; 66(4): 451-465. (In Ukrainian) Google Scholar

9. Kobiv Y. Response of rare alpine plant species to climate change in the Ukrainian Carpathians. Folia Geobotanica, 2017; 52: 217-226.

Crossref • Google Scholar

10. Kobiv Y. Trends in population size of rare plant species in the alpine habitats of the Ukrainian Carpathians under climate change. Diversity, 2018; 10(3): 62.

Crossref $\bullet$ Google Scholar

11. Körner C. Alpine plant life: functional plant ecology of high mountain ecosystems. SpringerVerlag Berlin Heidelberg, 2003. 344 p.

Crossref $\bullet$ Google Scholar

12. Kyyak V., Bilonoga V., Dmytrakh R., Gynda L., Nesteruk Y., Shtupun V. Changes in plant population pattern under the natural and man-induced ecosystem transformations of high mountain zone of Ukrainian Carpathians. Forum Carpaticum, Lviv, 2014; 58-60.

13. Kyyak V., Bilonoga, V., Dmytrakh R., Gynda L., Nesteruk Y., Shtupun V. Trends in plant population pattern changes under natural and man-induced ecosystem transformations of the high-mountain zone in the Ukrainian Carpathians. Studia Biologica, 2015; 9(2): 169-180. Crossref $\bullet$ Google Scholar

14. Kyyak V., Kobiv Y., Zhilyaev G., Bilonoga V., Dmytrakh R., Mykitchak T., Reshetylo O., Kobiv V., Nesteruk Y., Shtupun V., Gynda L. Changes in population structure of rare species in the high-mountain zone of the Carpathians and problems of their conservation. (Ed. V. Kyyak). Lviv: NNVK "ATV", 2018. 280 p. (In Ukrainian)

15. Kyyak V., Kobiv Y., Zhilyaev G., Bilonoga V., Dmytrakh R., Mykitchak T., Reshetylo O., Kobiv V., Nesteruk Y. Changes in population structure of rare species in the high-mountain zone in the Ukrainian Carpathians and problems of their conservation. Acta Biologica Univertatis Daugavpilinsis, 2019; 19(1): 77-85.

Google Scholar

16. Pauli H., Gottfried M., Reiter K., Klettner C., Grabherr G. Signals of range expansions and contracrions of vascular plants in the high Alps: observations (1994-2004) at the GLORIA master site Schrankogel, Tyrol, Austria. Global Change Biology, 2007; 13(1): 147-156. Crossref • Google Scholar

17. Rabotnov T.A. Experimental fitocenology. M.: Lomonosov Moscow State University, 1987. 160 p. (In Russian)

Google Scholar

18. Stoyko S.M. The impact of global climate changes on dynamic trends of vegetation belts of the Ukrainian Carpathians. Ukrainian Botanical Journal, 2012; 69(1): 3-16. (In Ukrainian) Google Scholar

19. Tsaryk Y., Zhilyaev G., Kyyak V., Kobiv Y., Danylyk I., Dmytrakh R., Bilonoga V., Sytschak N., Reshetylo O., Mykitchak T., Nesteruk Y., Kobiv V., Gynda L. Viability of plant populations of high-mountain zone of the Ukrainian Carpathians. (Ed. Y. Tsaryk). Lviv: Mercator, 2009; 172 p. (In Ukrainian)

20. Tsaryk Y., Kyyak V., Dmytrakh R., Bilonoga V. Generative reproduction of plant populations in high-mountain zone of the Ukrainian Carpathians as a sing of their viability. Visnyk of Lviv University. Biological series, 2004, 36: 50-56. (In Ukrainian) Google Scholar

21. Walther G.-R., Beißner S., Burga C.A. Trends in the upward shift of alpine plants. Journal of Vegetation Sciences, 2005; 16(5): 541-548.

Crossref $\bullet$ Google Scholar

ISSN 1996-4536 (print) • ISSN 2311-0783 (on-line) • Біологічні Студії / Studia Biologica • 2021 • Том 15 / № 1 • C. 67-78 
22. Zlobin Y. Plant population ecology: present condition, growing points. Sumy: University book, 2009. 263 p. (In Russian)

Google Scholar

23. Zlobin Y., Skliar V., Klymenko A. Populations of rare plant species: theoretical basis and learning methodology. Sumy: University book, 2013. 439 p. (In Russian)

Google Scholar

\title{
ВПЛИВ ПРИРОДНИХ ЧИННИКІВ НА ПОПУЛЯЦІЙНІ ЗМІНИ ТРАВ'ЯНИХ ВИДІВ РОСЛИН ТА ОЦІНКА ЇХНЬОГО СТАНУ В СУЧАСНИХ УМОВАХ ВИСОКОГІР'Я УКРАЇНСЬКИХ КАРПАТ
}

\author{
P. Дмитрах \\ Інститут екології Карпат НАН України, вул. Козельницька, 4, Львів 79026, Україна \\ Кореспондуючий автор е-mail: ecoinst@mail.Iviv.uа
}

Вступ. Природні екосистеми Українських Карпат упродовж останніх років зазнають значних трансформацій унаслідок впливу кліматичних чинників і зростання активності процесів відновлення. Дослідження впливу чинників зовнішнього середовища на популяції трав'яних видів рослин є особливо актуальними в гірських екосистемах. Унаслідок поступового відновлення корінної рослинності відбуваються характерні зміни в структурній і просторовій організації популяцій багатьох видів трав'яних рослин. Відтак, важливою $є$ оцінка сучасного стану популяцій, їхньої здатності до відновлення, реакції на зміну умов та особливостей прояву індивідуального характеру поведінки в екологічно змінених умовах середовища.

Матеріали і методи. 3 метою встановлення змін у структурній організації популяцій високогірних видів та їхньої здатності до відновлення використано загальноприйняті стаціонарні й маршрутно-польові методи досліджень. Вихідними ознаками діагностики стану популяцій $є$ індивідуальні особливості їхнього розвитку та характер прояву динамічних тенденцій у змінених умовах середовища. Під час онтогенетичного розвитку рослин найістотніші зміни відбуваються в генеративній фазі, що $€$ важливою індикаційною ознакою, якою забезпечується відновлення й самопідтримання популяцій насінням. 3 цією метою застосовано довготривалі багаторічні спостереження в різних типах рослинних угруповань, що передбачає облік основних параметрів і ознак на постійних пробних площах. Трансекти розташовані в альпійському, субальпійському і верхньому лісовому поясах Українських Карпат у діапазоні висот 1000-2000 м н.р.м. Дослідженнями охоплені такі поведінкові ознаки популяцій видів як фенологічні (зміщення фенофраз, ритміка цвітіння), демографрічні (чисельність, просторова диференціація), репродуктивні (генеративне розмноження, насіннєва продуктивність) та ін., що дають змогу з'ясувати їхню адаптацію та здатність до існування у змінених умовах середовища.

Результати досліджень. Тривалим моніторингом, проведеним у різних рослинних угрупованнях високогір'я, з'ясовано, що в одних випадках зростає участь видів, які вирізняються активною стратегією відновлення та її спрямуванням на подальше розширення меж, а в інших - мають протилежний характер, що пов'язано з неспроможністю адаптуватися до змін умов середовища. Встановлено, що вегетаційний розвиток популяцій гірських видів рослин тісно пов'язаний з режимом температурних умов, а це впливає на фенологію, динаміку чисельності особин і характер їхнього

ISSN 1996-4536 (print) • ISSN 2311-0783 (on-line) • Біологічні Студії / Studia Biologica • 2021 • Том 15 / № 1 • С. $67-78$ 
розмноження. Про істотний вплив потепління на процеси сезонного розвитку популяцій і рясність їхнього цвітіння свідчить збільшення чисельності генеративних особин у популяціях гірських видів та їхня міграція на значно вищі гіпсометричні рівні високогір'я. Підвищена здатність до генеративного розмноження сприяє розселенню насіння та появі нових популяційних локусів Valeriana simplicifolia, V. transsilvanica, Silene dioica, Astrantia major, Doronicum carpaticum, Euphorbia carniolica та ін. у сприятливих для них мікрооселищах на значно вищих гіпсометричних рівнях високогір'я (1600-2000 м н.р.м.). Іншим природним чинником змін для популяцій видів $\epsilon$ вплив демутаційних перетворень у різних типах рослинних угруповань. Ці зміни здебільшого супроводжуються посиленням затінення й ущільненням рослинного покриву внаслідок поширення конкурентноздатніших деревно-чагарникових і адвентивних видів високотрав'я. Насамперед це стосується лучних видів, які потребують відкритих ділянок для ефективного самовідновлення популяцій. 3 підвищенням ценотичної активності більш конкурентноздатних видів у структурній організації популяцій спостерігають зміни, які знижують здатність до поновлення та призводять до їхньої фрагментації. Відповідно, зміни еколого-ценотичних умов у різних типах рослинних угруповань уздовж висотного градієнта високогір'я зумовлюють різну специфіку існування популяцій видів і їхню неоднакову просторову диференціацію.

Висновки. Сучасні природні процеси, які відбуваються в популяціях видів трав'яних рослин високогір'я мають неоднозначний вплив на здатність до відновлення та характер змін у їхній структурній організації. У кожному окремому випадку динаміка популяцій визначається впливом природно-кліматичних змін і їхню приуроченістю до конкретних рослинних угруповань уздовж висотного градієнта високогір'я. Багаторічна динаміка чисельності генеративних особин характеризує їхню здатність до відновлення та залежність від метеоумов. Важливою рисою відновлення популяцій є розвиток локальних осередків у сприятливих для них мікрооселищах високогір'я, зокрема, у верхньому субальпійському й альпійському поясах. Поява нових популяційних локусів $€$ показником їхньої здатності до відновлення та виживання. В одних випадках динамічні тенденції в популяціях супроводжуються збільшенням чисельності особин і розширенням їхніх меж, а в інших вони мають протилежний характер, що пов'язано зі зменшенням їхньої чисельності та деградацією. У відновленні популяцій видів спостерігають процеси, пов'язані як з висхідним поширенням їх на різних гіпсометричних рівнях, так і з посиленням позицій популяцій видів деревно-чагарникового ярусу й адвентивних представників високотрав'я, характерних для нижчих висот. В оселищах популяцій багатьох видів трав'яних рослин на верхній межі лісового та субальпійського поясу мають місце значні процеси заростання, внаслідок яких відбувається поступове витіснення характерних для лучних угруповань трав'яних видів. Відтак, зміна еколого-ценотичних умов у різних рослинних угрупованнях уздовж висотного градієнта високогір'я зумовлюють різну специфіку існування популяцій видів трав'яних рослин і їхню неоднакову просторову диференціацію.

Ключові слова: кліматичні зміни, генеративне розмноження, здатність до відновлення, високогір'я

Received / Одержано 15 February, 2021 Revision / Доопрацьовано
27 February, 2021
Accepted / Прийнято 17 March, 2021
Published / Опубліковано 31 March, 2021

ISSN 1996-4536 (print) • ISSN 2311-0783 (on-line) • Біологічні Студії / Studia Biologica • 2021 • Том 15 / № 1 • C. 67-78 